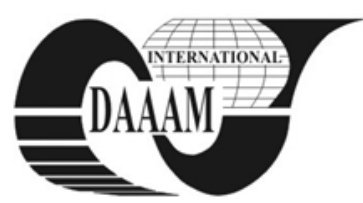

Annals of DAAAM for 2011 \& Proceedings of the 22nd International DAAAM Symposium, Volume 22, No. 1, ISSN 1726-9679 ISBN 978-3-901509-83-4, Editor B. Katalinic, Published by DAAAM International, Vienna, Austria, EU, 2011 Make Harmony between Technology and Nature, and Your Mind will Fly Free as a Bird

\title{
SAILCLOTH SORPTION PROPERTIES AS AN OBJECTIVE INDICATOR OF QUALITY
}

\author{
VUJASINOVIC, E[dita]; PUSIC, T[anja]; DRAGCEVIC, K[resimir] \& DRAGCEVIC, Z[vonko]
}

\begin{abstract}
Objective description and evaluation of sails is a complex and demanding task, especially nowadays when a great number of fibres and sailcloth constructions are present on the market. While some of sail's quality descriptors like resistance to weathering and forces are well explored and explained some of them e.g. sorption properties are still not fully clarified. So, in this paper we put our attention on sail's sorption properties and their possibilities to become sail's care quality indicator.
\end{abstract}

Key words: sailcloth, sails, sorption properties, wetting

\section{INTRODUCTION}

While some of sail's quality descriptors like resistance to weathering and different kind of forces are well explored and explained (Vujasinovic et al., 2004) some of them, e.g. sorption properties are still not fully clarified.

Sorption properties started to attract sail-makers attention back in the 1851 when schooner America win the Hundred Guineas Cup (today known as famous America's Cup), thanks to its cotton sails which were more stronger and elastic than other flax sails and besides that cotton has lower sorption properties than flax and correspondingly to that lower weight of sails what become crucial element in wining the race. Today when sails weight can be designed and engineered by the use of different kind of high performance fibres, micro- and macro construction of sailcloth (Vujasinovic et al., 2007) we assume that, sorption properties of a sails could still be a valuable data that can be used for the prediction of sails usability and recommendation for their proper care in use.

\section{EXPERIMENTAL PART}

\subsection{Methodology}

Although, generally speaking, modern sails exhibit low sorption properties that are desirable in use and which can be achieved by the use of low sorption fibres and specific construction of sailcloth sometimes, they act as highly absorbent materials what could be explained by the fact that they are regularly exposed to the direct action of water (marine and atmospheric).

In order to determine such kind of sails sorption properties sailcloth were subjected to the action of water and sea water and their wetting abilities (Tab.1) were find out.

\subsection{Tested samples}

To explore possibilities of an objective characterization of sailcloth sorption properties, eight different samples were selected (Tab.2). Thanks to their mutual differences in construction and/or raw material content, these samples fully represent a wide range of textile fabrics intended for sail making that are now available on the market.

\begin{tabular}{|c|c|}
\hline Method & $\begin{array}{l}\text { Determination of wetting angle - drop method } \\
\text { (Pastore \& Kiekens, 2001; Slater, 1993). }\end{array}$ \\
\hline Apparatus & $\begin{array}{l}\text { Goniometer NRL C.A. Model No. A } 100 \text { Rame- } \\
\text { hart; instrument error: } \pm 2^{\circ}\end{array}$ \\
\hline $\begin{array}{l}\text { Wetting } \\
\text { liquids }\end{array}$ & $\begin{array}{l}\text { Distilled water; surface tension } \gamma_{\mathrm{DH} 2 \mathrm{O}}=72.75 \\
\mathrm{mNm}^{-1} \text {; synthetic sea water (DIN 50907); } \\
\text { surface tension } \gamma_{\text {sea water }}=73.54 \mathrm{mNm}^{-1} \text {. } \\
\text { Water temperature: } 20 \pm 1^{\circ} \mathrm{C} \text {. }\end{array}$ \\
\hline Procedure & $\begin{array}{l}\text { Contact angle is determined from the left and } \\
\text { right side of drop and mean value is then } \\
\text { calculated. For each sample } 5 \text { parallel } \\
\text { measurements on the face }\left(\mathrm{F}_{\mathrm{M}}\right) \text { and reverse or } \\
\text { back side }\left(\mathrm{B}_{\mathrm{M}}\right) \text { of sample were done. }\end{array}$ \\
\hline Results & 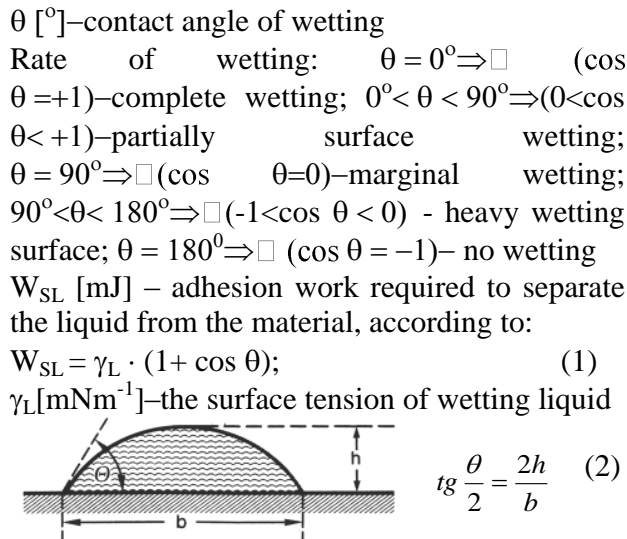 \\
\hline
\end{tabular}

Tab. 1.Determination of sails wetting ability

\begin{tabular}{|c|l|l|l|}
\hline Sample & Trade name & Producer & Description \\
\hline 1 & 3.7 us oz & $\begin{array}{l}\text { Polyant } \\
\text { USA }\end{array}$ & $\begin{array}{l}\text { Woven sailcloth; } \mathrm{m}_{\mathrm{a}}< \\
160 \mathrm{gm}^{-2}\end{array}$ \\
\hline 2 & $\begin{array}{l}\text { Cuben fibre 0.3 } \\
\text { mil film; 0.9 us } \\
\text { oz }\end{array}$ & $\begin{array}{l}\text { Cuben } \\
\text { USA }\end{array}$ & $\begin{array}{l}\text { Laminated sailcloth; } \\
\mathrm{m}_{\mathrm{a}}<30 \mathrm{gm}^{-2} ; \text { film } \\
\text { thickness } 7.6 \mu \mathrm{m}\end{array}$ \\
\hline 3 & $\begin{array}{l}\text { Spectra } 1.8 \text { us } \\
\text { oz }\end{array}$ & $\begin{array}{l}\text { Bainbridge } \\
\text { USA }\end{array}$ & $\begin{array}{l}\text { Laminated Spectra } \\
\text { fibres; } \mathrm{m}_{\mathrm{a}}<80 \mathrm{gm}^{-2}\end{array}$ \\
\hline 4 & $\begin{array}{l}\text { Polyester 1.8 us } \\
\text { oz }\end{array}$ & $\begin{array}{l}\text { Bainbridge } \\
\text { USA }\end{array}$ & $\begin{array}{l}\text { Laminated PES fibres; } \\
\mathrm{m}_{\mathrm{a}}<80 \mathrm{gm}^{-2}\end{array}$ \\
\hline 5 & $\begin{array}{l}\text { Kevlar 0.75 } \\
\text { mil; } 1.5 \text { us oz }\end{array}$ & $\begin{array}{l}\text { Dimension } \\
\text { USA }\end{array}$ & $\begin{array}{l}\text { Laminated Kevlar } \\
\text { fibres; } \mathrm{m}_{\mathrm{a}}<100 \mathrm{gm}^{-2} ; \\
\text { film thickness } 19.1 \mu \mathrm{m}\end{array}$ \\
\hline 7 & $\begin{array}{l}\text { Kevlar with X } \\
\text { ply; } 2.4 \text { us oz }\end{array}$ & $\begin{array}{l}\text { Dimension } \\
\text { USA }\end{array}$ & $\begin{array}{l}\text { Laminated Kevlar } \\
\text { with additional X } \text { scrim; } \\
\mathrm{m}_{\mathrm{a}}<110 \mathrm{gm}^{-2}\end{array}$ \\
\hline 8 & $\begin{array}{l}\text { Monofilm } 3.1 \\
\text { us oz }\end{array}$ & $\begin{array}{l}\text { Bainbridge } \\
\text { USA }\end{array}$ & $\begin{array}{l}\mathrm{M}_{\mathrm{a}}<210 \mathrm{gm}^{-2} \\
\mathrm{gm}^{-2}\end{array}$ \\
\hline
\end{tabular}

Tab. 2.Description of the sailcloth samples

Wetting angle greater than $90^{\circ}$ indicates the success of hydrophobic finishes of woven sailcloth made of PES (sample 1). Sample 8 marginal wetting and a slight moistening of laminated samples (samples 2-7) may be associated with prominent surface roughness of these samples, among which 
the sample 3 is the roughest one and with the greatest variations in individual values of wetting angle ( $\mathrm{CV}=3.7$ to $4.2 \%)$.

Contact angle of wetting (Tab. 3) was higher in the system with sea water than in the system with distilled water. Such behaviour of the sailcloth's surface in relation to the composition of the liquid phase is characterized by the occurrence of adhesion wetting, and can be interpreted as a consequence of increased surface tension and specific mass of sea water $\left(\rho_{\text {sea water } / 20^{\circ} \mathrm{C}}=1.0239 \mathrm{gcm}^{-3} ; \gamma_{\text {sea water }}=73.53 \mathrm{mNm}^{-1}\right)$ compared to distilled water $\left(\rho_{\text {distilled water } / 20^{\circ} \mathrm{C}}=0.9982 \mathrm{gcm}^{-3}\right.$; $\left.\gamma_{\text {distilled water }}=72.52 \mathrm{mNm}^{-1}\right)$.

Although, considering its end purpose, sailcloth material should have the same features on both sides (face and back); according to the table 3 differences in wetting behaviour were found in all samples except for sample 3 and 8 (shown through $\cos \theta$ and $\mathrm{W}_{\mathrm{SL}}$ ). This phenomenon can be explain with the type and construction of sailcloth e.g. through approximately the same roughness and/or smoothness of both material's side (the face $-\mathrm{F}_{\mathrm{M}}$ and reverse $-\mathrm{B}_{\mathrm{M}}$ ).

With regard to the determined work of adhesion and its limit $\left(\mathrm{W}_{\mathrm{SL}}\right.$ for distilled water $=72.52 \mathrm{~mJ} ; \mathrm{W}_{\mathrm{SL}}$ for sea water $=$ $73.53 \mathrm{~mJ}$ ) the lowest energy or work required to separate the liquid from samples is associated with woven sample, which once again prove its extreme hydrophobicity. However, with the substantial difference in value for the two sides and the fact that proper material's finishing for such specific purpose, tolerate the maximum difference of the face and reverse of \pm $10 \%$ (which is considerably lower than for sample $2 \sim 26.9 \%$ ), the apparent gap in surface finishing is recorded (later confirmed with microscopic examination (Fig. 1).

This is additionally confirmed with the values for the adhesion work on face and reverse side and their wetting with distilled water $\left(\mathrm{W}_{\mathrm{SL}}>\right.$ limiting value $\left.=72.52 \mathrm{~mJ}\right)$. This is why the reverse side of sample 1 can be classified as partially wetted surface.
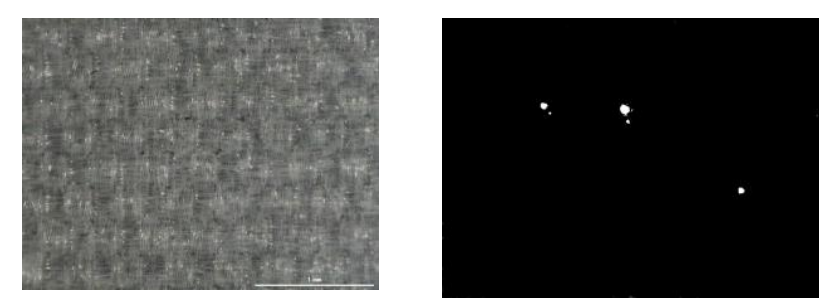

Fig. 1. Microscopic appearance of sample 1; left-original appearance; right-binary picture (white spots shows damages in finishing layer)

Signification of differences in sailcloth wetting angle and adhesion work for sea and distilled water of almost all samples (except sample 3 and 8) were confirmed by ANOVA analysis. That is why we may assume that wetting properties of sailcloth depend not only on kind of wetting liquids but also on macroand micro-structure of sailcloth surface exposed to wetting.

\section{CONCLUSION}

Since the wetting angle of sailcloth samples is greater with sea water, and in regard to this less energy is required for sea water separation from the sail, the greater problems in the maintenance and use of sails (harder to separate; slower drying) will be seen at the sail exposed to the action of atmospheric precipitation than at the sails exposed only to the sea water.

Reduction of the work (energy) necessary to remove the liquid phase in the system with sea water significantly reduces the time of liquid phase existence on the surface of the sail. The energy required to remove the liquid phase (droplets of water) from the surface of the sails is significantly lower (48.88 to
$102.5 \mathrm{~mJ}$ ) than the energy needed to evaporate the liquid phase (11.29 J at water vapour pressure of $233.5 \mathrm{~Pa}$ and $20^{\circ} \mathrm{C}$ ). So, the liquid phase from the surface of the sail will be removed completely by draining mechanism, while the mechanism of evaporation will be only marginally represented, and there will be no crystallization of salts on the surface of the sails.

Therefore, during sail care and maintenance it is significant to dry sails in a vertical position (freely suspended) and when not in use to protect them from possible condensation of water on their surface.

\begin{tabular}{|c|c|c|c|c|c|c|c|}
\hline Sample & $\begin{array}{l}\text { Wetting } \\
\text { liquid }\end{array}$ & $\begin{array}{c}\text { Sample } \\
\text { side }\end{array}$ & $\begin{array}{l}\Theta_{\mathrm{s}} \\
{\left[{ }^{0}\right]}\end{array}$ & $\cos \Theta$ & $\begin{array}{l}\mathrm{CV} \\
{[\%]}\end{array}$ & $\begin{array}{l}\mathrm{W}_{\mathrm{SL}} \\
{[\mathrm{mJ}]}\end{array}$ & $\begin{array}{l}\mathrm{CV} \\
{[\%]}\end{array}$ \\
\hline \multirow{4}{*}{1} & \multirow{2}{*}{\begin{tabular}{|l|} 
distilled \\
water \\
\end{tabular}} & $\mathrm{F}_{\mathrm{m}}$ & 107.0 & -0.3 & 2.9 & 51.34 & 7.27 \\
\hline & & $\mathrm{B}_{\mathrm{m}}$ & 99.2 & -0.2 & 1.8 & 60.92 & 3.66 \\
\hline & \multirow{2}{*}{\begin{tabular}{|l|} 
sea \\
water \\
\end{tabular}} & $\mathrm{F}_{\mathrm{m}}$ & 97.2 & -0.1 & 2.3 & 64.33 & 4.51 \\
\hline & & $\mathrm{B}_{\mathrm{m}}$ & 108.4 & -0.3 & 2.5 & 50.35 & 6.53 \\
\hline \multirow{4}{*}{2} & \multirow{2}{*}{\begin{tabular}{|l|} 
distilled \\
water
\end{tabular}} & $\mathrm{F}_{\mathrm{m}}$ & 76.4 & 0.2 & 2.0 & 89.55 & 2.08 \\
\hline & & $\mathrm{B}_{\mathrm{m}}$ & 65.6 & 0.4 & 2.3 & 102.45 & 1.71 \\
\hline & \multirow{2}{*}{\begin{tabular}{|l|} 
sea \\
water \\
\end{tabular}} & $\mathrm{F}_{\mathrm{m}}$ & 78.4 & 0.2 & 2.1 & 88.32 & 2.38 \\
\hline & & $\mathrm{B}_{\mathrm{m}}$ & 66.8 & 0.4 & 2.0 & 102.50 & 1.50 \\
\hline \multirow{4}{*}{3} & \multirow{2}{*}{$\begin{array}{l}\text { distilled } \\
\text { water }\end{array}$} & $\mathrm{F}_{\mathrm{m}}$ & 79.4 & 0.2 & 3.7 & 85.83 & 4.29 \\
\hline & & $\mathrm{B}_{\mathrm{m}}$ & 79.6 & 0.2 & 2.1 & 85.59 & 2.43 \\
\hline & \multirow{2}{*}{\begin{tabular}{|l|} 
sea \\
water \\
\end{tabular}} & $\mathrm{F}_{\mathrm{m}}$ & 82.6 & 0.1 & 4.2 & 82.99 & 5.36 \\
\hline & & $\mathrm{B}_{\mathrm{m}}$ & 83.0 & 0.1 & 3.7 & 82.49 & 4.76 \\
\hline \multirow{4}{*}{4} & \multirow{2}{*}{\begin{tabular}{|l|} 
distilled \\
water \\
\end{tabular}} & $\mathrm{F}_{\mathrm{m}}$ & 85.6 & 0.1 & 1.6 & 78.07 & 2.17 \\
\hline & & $\mathrm{B}_{\mathrm{m}}$ & 81.2 & 0.2 & 2.8 & 83.59 & 3.41 \\
\hline & \multirow{2}{*}{ sea water } & $\mathrm{F}_{\mathrm{m}}$ & 89.2 & 0.0 & 2.4 & 74.56 & 3.73 \\
\hline & & $\mathrm{B}_{\mathrm{m}}$ & 86.6 & 0.1 & 1.3 & 77.90 & 1.87 \\
\hline \multirow{4}{*}{5} & \multirow{2}{*}{\begin{tabular}{|l|} 
distilled \\
water \\
\end{tabular}} & $\mathrm{F}_{\mathrm{m}}$ & 78.4 & 0.2 & 2.1 & 87.08 & 2.38 \\
\hline & & $\mathrm{B}_{\mathrm{m}}$ & 72.6 & 0.3 & 4.1 & 94.16 & 3.82 \\
\hline & \multirow{2}{*}{\begin{tabular}{|l|} 
sea \\
water \\
\end{tabular}} & $\mathrm{F}_{\mathrm{m}}$ & 82.2 & 0.1 & 1.8 & 83.51 & 2.26 \\
\hline & & $\mathrm{B}_{\mathrm{m}}$ & 75.8 & 0.2 & 2.2 & 91.57 & 2.23 \\
\hline \multirow{4}{*}{6} & \multirow{2}{*}{\begin{tabular}{|l} 
distilled \\
water \\
\end{tabular}} & $\mathrm{F}_{\mathrm{m}}$ & 77.6 & 0.2 & 2.0 & 88.07 & 2.13 \\
\hline & & $\mathrm{B}_{\mathrm{m}}$ & 84.2 & 0.1 & 1.8 & 79.83 & 2.34 \\
\hline & \multirow{2}{*}{ sea water } & $\mathrm{F}_{\mathrm{m}}$ & 82.0 & 0.1 & 1.7 & 83.77 & 2.14 \\
\hline & & $\mathrm{B}_{\mathrm{m}}$ & 85.2 & 0.1 & 1.0 & 79.69 & 1.34 \\
\hline \multirow{4}{*}{7} & \multirow{2}{*}{\begin{tabular}{|l} 
distilled \\
water \\
\end{tabular}} & $\mathrm{F}_{\mathrm{m}}$ & 81.2 & 0.2 & 7.5 & 83.55 & 9.06 \\
\hline & & $\mathrm{B}_{\mathrm{m}}$ & 73.0 & 0.3 & 3.1 & 93.69 & 2.89 \\
\hline & \multirow{2}{*}{$\begin{array}{l}\text { sea } \\
\text { water }\end{array}$} & $\mathrm{F}_{\mathrm{m}}$ & 83.4 & 0.1 & 4.3 & 81.97 & 5.55 \\
\hline & & $\mathrm{B}_{\mathrm{m}}$ & 76.2 & 0.2 & 1.9 & 91.07 & 2.03 \\
\hline \multirow{4}{*}{8} & \multirow{2}{*}{$\begin{array}{l}\text { distilled } \\
\text { water }\end{array}$} & $\mathrm{F}_{\mathrm{m}}$ & 84.4 & 0.1 & 0.6 & 79.58 & 0.87 \\
\hline & & $\mathrm{B}_{\mathrm{m}}$ & 84.4 & 0.1 & 1.1 & 79.58 & 1.41 \\
\hline & \multirow{2}{*}{$\begin{array}{l}\text { sea } \\
\text { water }\end{array}$} & $\mathrm{F}_{\mathrm{m}}$ & 87.4 & 0.0 & 1.0 & 76.87 & 1.49 \\
\hline & & $\mathrm{B}_{\mathrm{m}}$ & 86.8 & 0.1 & 1.0 & 77.64 & 1.38 \\
\hline
\end{tabular}

Tab. 3. Contact wetting angle $\left(\Theta_{\mathrm{s}}\right)$ for the face $\left(\mathrm{F}_{\mathrm{m}}\right)$ and back $\left(\mathrm{B}_{\mathrm{m}}\right)$ side of tested sailcloth (samples 1-8) and adhesion work $\left(\mathrm{W}_{\mathrm{SL}}\right)$ required for separating liquids from the sailcloth

\section{REFERENCES}

Pastore, C. \& Kiekens, P. (2001). Surface Characteristics of Fibres and Textiles, CRC Press, ISBN-10: 0824700023, UK

Slater, K. (1993). Chemical Testing and Analysis. Textile Progress, Vol. 251, No. 2, 1-150, ISSN 00405167

Vujasinovic, E. et al. (2004). Micro \& Macro Construction Features of Technical Textiles for Sailmaking, DAAAM International Scientific Book 2004, Katalinic B. (Ed.), pp. 645-670, Pub. DAAAM International, ISBN 3-901509-380 , Vienna, Austria

Vujasinovic, E. et al. (2007). Research and development in the field of sailcloth, Book of proceedings of ,AGILTEX Design”, Curteza, A. (Ed.), pp. 50-66, Iasi, September 2007, The Gh. Asachi Technical University, Iasi, Romania 